\title{
Electric Vehicle Policy Based on Juridical Foundation to Realize Environmental Resilience in Indonesia
}

\author{
Erna Yuliandari, Lionie Natasha Violie \\ Faculty of Teacher Training and Education, Faculty of Law, Sebelas Maret University \\ *Corresponding author Email: ernayuliandari@staff.uns.ac.id,
}

\begin{abstract}
The rapid advancement of technology affects the increasing number of industrial developments and transportation facilities, in line with the increase, followed by the number of fuel users, especially fuel oil (BBM). With increased fuel oil users, especially fuel from fossil fuels, there are an increase in carbon dioxide exhaust gases $\left(\mathrm{CO}_{2}\right)$ emissions as a combustion gas from fossil fuels. Air pollution, greenhouse gas emissions, and climate change are also worrying impacts. The Government's policy to agree to the Paris Agreement aims to slow climate change and develop sustainable energy sources. In order to succeed in the Paris Agreement, the Government took steps to turn the previously oil-fueled automotive industry into an electric motor vehicle (KBL). KBL is considered an innovative and solutive program in reducing exhaust emissions due to increasing means of transportation. Nevertheless, the application of electric motor vehicle policies must still be reviewed in ecological resilience to minimize environmental damage related to quality to survival. However, the survival and growth in national life, especially in terms of the environment, become better by reducing pollution using electric cars.
\end{abstract}

Keywords: Fuel Oil (BBM), exhaust emissions, carbon dioxide (CO $\left.\mathrm{C}_{2}\right)$, Electric Motor Vehicles (KBL)

\section{INTRODUCTION}

\subsection{Background}

Today the use of fuels such as petroleum and coal is the primary source of energy for the world, especially in Indonesia. However, burning fuel has a destructive impact with reduced environmental quality, including air pollution, greenhouse gas emissions, and global warming. Compounds contained from exhaust emissions themselves include carbon monoxide $(\mathrm{CO})$, carbon dioxide $_{(\mathrm{CO} 2)}$, various hydrocarbon compounds, various nitrogen oxides $\left(\mathrm{NO}_{\mathrm{x}}\right)$ and sulfur $\left(\mathrm{SO}_{\mathrm{x}}\right)$. Emissions of gases from burning fuels such as hydrocarbon compounds are released into the air due to evaporation from the fuel system. The formation of exhaust gases occurs during the combustion of diesel fuel in the engine.
The formation of exhaust gases has seen a significant increase in the concentration of $\mathrm{CO}_{\mathrm{CO}}$ compounds in the atmosphere, which is estimated to exceed 417 parts per million (ppm) and an increase of $50 \%$ since the start of industrial activity in the 18th century due to the continuous use of fuel (Novena, 2021). Burning fuel that produces fuel oil (BBM) is often used for all industrial processes and as a fueling mode of transportation of motor vehicles. In line with the high number of industries and transportation facilities in the world has undoubtedly increased the amount of fuel use and has an impact on increasing $\mathrm{CO}_{2}$ gas production.

The increase in harmful compounds is causing the planet to experience a climate change crisis, and now the state of the Earth is at a very worrying level. People around the world need so accurate and rapid action to 
restore the situation. Since the end of the last century, global temperatures have risen twice as fast and are expected to rise faster in the coming decades. This has the impact of climate change, weather patterns, and environmental damage that, if not immediately improved, will damage the order of human life, especially for those living in poverty who are most vulnerable to the effects.

Seeing increasingly dangerous climate change, the Government of Indonesia and 195 representatives of other countries agreed to form the Paris Agreement in the United Nations Framework Convention on Climate Change at the 21st UNITED NATIONS Climate Change Conference in Paris, France. The Government of Indonesia has ratified the Paris Agreement in Law No.16 of 2016 on the Ratification of the Paris Agreement To The United Nations Framework Convention on Climate Change. In order to meet the contents of the Paris Agreement and slow climate change, and develop sustainable energy resources, the Government of Indonesia began to expend considerable energy from fossil fuels to renewable energy and the use of alternative energy sources, including the change of oil-fueled motor vehicles to Electric Motor Vehicles (KBL) as energy-efficient future vehicles.

According to the results of studies and research initiated by the Ministry of Industry in collaboration with the Ministry of Research, Technology, and Higher Education University and the automotive industry stated that electric motor vehicles are considered able to save energy up to 80 per cent compared to conventional motor vehicles that use fuel oil. Then, the use of KBL can save fuel up to two times that is about 12 million kiloliters. If realized properly can reduce Greenhouse Effect Gas Emissions $(\mathrm{CO} 2)$ by 29\% by 2030 (Ministry of Industry Indonesia, 2018).

\subsection{Problem Formula}

As an effort to continue the transition of fossil fuel energy to renewable energy and alternative energy, electric vehicles are an innovative government program. They are beneficial in reducing the number of exhaust emissions. However, on the one hand, the program launched by the Government of Indonesia is a program that is considered very new which requires proper regulation so that the success rate is following what has been predicted. From the introduction of the above writing can be presented the formulation of the following problems:
1. What is the electric vehicle policy based on juridical foundations in Indonesia?

2. What is the impact of electric vehicles to realize environmental resilience?

\subsection{Research Methods}

The type of method carried out in this study is normative juridical research to review and find a government policy in the electric vehicle policy sector using literature studies. In conducting this study, the author used a method of statutory approach (statute approach). In this method, researchers need to understand the hierarchy and principles in the laws and regulations concerning electric vehicle policy. To review the laws and other laws related to legal issues. In addition, researchers also use the method of conceptual approach (conceptual approach). This type of approach in research provides an analytical point of view of aspects of legal concepts behind policy in this legal issue. It looks at the values contained in the inclusion of a rule and its relation to the concept used.

\section{LIBRARY REVIEW}

\subsection{Electric Vehicles}

The most widely used energy source in the world is fossil fuel oil. Indonesia is still very dependent on fossil energy. Fossil fuels still supply nearly $95 \%$ of Indonesia's energy needs. About 50\% of the fossil energy is petroleum, and the rest is gas and coal. Fossil energy is often called fuel (fuel oil). The transportation sector is the largest fuel user in terms of fuel use, with the proportion per year continuously increasing. Various kinds of alternative energy can be used to develop transportation facilities by manufacturing electric vehicles (Rahman, 2013).

Electric vehicle technology evolved over a hundred years ago. Initially, electric-based vehicles were popular compared to oil-fueled vehicles. Electric vehicles are helping to increase popularity in the community. The development of electric vehicles today has been in a condition where all supporting technologies have developed rapidly (Kumara and Sukareyasa, 2009).

Electric-based vehicle technology in Indonesia is a"disruptive technology" whose presence has been awaited to help reduce the use of diesel fuel and the effects of greenhouse gases, especially in transportation. The presence of electric-based vehicles in Indonesia will help on the environmental side by reducing air pollution and indirectly affecting the 
economic and energy sectors. The presence of electric vehicles in terms of energy can reduce dependence on fossil energy to achieve energy security. Reducing the use of fuel oil (BBM) can eventually cut crude oil imports that have the potential to save up to $\mathrm{Rp} 700$ trillion so that it greatly benefits the country's economy (Dawami et al., 2020).

\subsection{Juridical Foundation}

The Law in Indonesia's regulates the field of transportation into two forms of Law, some in the form of codification, namely the Code of Trade Law (hereinafter referred to as KUHD) and the Civil Law (starting now called KUHPerdata), there is in the form of ordinary laws, which are outside the kuhd and civil code. In the framework of traffic and road transportation implementation, Law No. 22 of 2009 was established on Traffic and Road Transport (from now on referred to as UULLAJ No. 22/2009). Broadly speaking, Article 47 paragraph (1) of UULLAJ No. 22/2009 classifies vehicles into two groups, namely motor vehicles and non-motorized vehicles. In general provisions, it is explained that a motor vehicle is any vehicle driven by mechanical equipment in the form of machinery other than a vehicle that runs on rails. In contrast, a non-motorized vehicle is any vehicle driven by human and/ or animal power ${ }^{[2]}$ (Arsari, 2020).

The Government has issued Government Regulation No. 55 of 2019 on specific mechanisms that make it easier for electric vehicle industry players to develop their businesses and encourage people to use electric vehicles. The provision of this convenience is motivated by environmentally friendly conditions such as clean air and decreased greenhouse gas emissions using electric vehicles (Alif, 2021).

Through the Ministry of Transportation, the Government has rolled out two regulations (regulations) related to motor vehicles with electricpowered motor drives. First, the Minister of Transportation (PM) No. 44 of 2020 on Physical Type Testing. Second, The Minister of Transportation Regulation (PM) No. 45 of 2020 on Certain Vehicles using Electric Motor Drive. Both ministerial regulations are prepared as a legal basis that regulates several provisions/prerequisites for using motor vehicles with electric drive in operating on public roads as one of the modes of land transportation (Ministry of Transportation of the Republic of Indonesia, 2020).

\subsection{Environmental Resilience}

The transportation sector plays an essential role in determining national energy demand. The provision of energy for transportation requires more specialized attention. Most of the transportation sectors worldwide use petroleum-derived fuels with an average growth of about $2.5 \%$ per year. The energy used for the transportation sector shows a trend that is prone to scarcity. Considering national biomass energy sources, total national energy consumption will increase to 298 million tonnages of oil equivalent (TOE). The transportation sector will experience scarcity when it relies only on conventional fuels and biomass. The use of electric vehicles is one way to reduce the use of conventional fuel. In terms of energy use, electric vehicles are also more profitable, with an efficiency range of 90\% (Wirabrata, 2019).

According to the Ministry of Energy and Mineral Resources (ESDM) data, $\mathrm{CO} 2$ emissions from pure electric cars are only 0-5 grams $/ \mathrm{km}$, while $\mathrm{CO} 2$ emissions from conventional cars reach 125 grams $/ \mathrm{km}$. In addition to $\mathrm{CO} 2$ emissions, electric cars also account for $11-13 \%$ less PM 2.5 pollutants than conventional cars. Electric cars also contribute to the reduction of greenhouse gas emissions. The Ministry of Industry targets 600 thousand units of electric cars by 2030 to reduce 2.7 million tons of $\mathrm{CO} 2$ emissions. In addition to minimal air pollution, the use of electric cars is also minimal noise pollution. The noise level of electric cars is only 21 decibels, compared to the noise level in Jakarta, which reaches 76 decibels (Hartriani, 2021).

\section{DISCUSSION}

\subsection{Electricity Vehicle Policy Based on Juridical Foundation in Indonesia}

The major transformation of the automotive industry into the era of electric vehicles around the world led the Government of Indonesia to strategize from the beginning to welcome zero-emission motor vehicles by 2030 . The spirit of the Government of Indonesia in accelerating the development of the Electric Vehicle Program has been contained in the draft regulations formed by the Government. It now reportedly has become a positive law in Indonesia. The first regulation legalized by the Government regarding Electric vehicles is Presidential Regulation (Perpres) Number 55of 2019 on Accelerating battery-based electric vehicle program on August 12, 2019. 
The Presidential Regulation regulates several matters, including regulatory authority, coverage of electric motor vehicles (KBL), kbl program acceleration strategy, transition strategy from KBM to KBL, and kbl technical provisions. The contents of the Perpres are as follows (Tumiwa, 2019) :

A. The regulatory authority that has been stated in the Presidential Regulation is the basis of the KBL arrangement and mainly contains industrial development and coordination carried out by the Coordination Team chaired by the Ministry of Maritime Affairs and its representatives of the Ministry of Economic Affairs, and nine ministries/institutions as members, assisted by a working group.

\section{B. Coverage}

The scope of electric motor vehicles based on the Perpres is under Article 2 paragraph (1) contains the type of battery-based KBL group, namely KBL-based two-wheeled and / or three-wheeled batteries; and KBL-based batteries or more. Then the scope of motor vehicle functions following legislation in the field of road transport traffic facilities and infrastructure.

The type of motor vehicle in Law No. 22/2009 consists of motorcycles, passenger cars, bus cars, freight cars and special vehicles.

\section{KBL program acceleration strategy}

Accelerated development of battery-based KBL industry

Referring to the road map for the development of the national motor vehicle industry set by the Minister of Industry [Article 4 paragraph (1)]

KBL industry and KBL component industry [Article 5 paragraph (1)], building facilities in the country [Article 6 paragraph (1)]

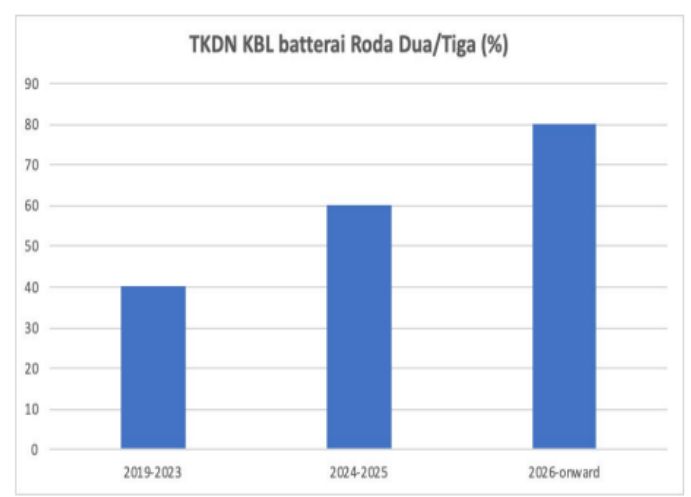

Figure 1. Percentage TKDN KBL Two-wheeled and/or three-wheeled battery
Domestic KBL component industry must cooperate with the domestic KBL industry [Article 6 paragraph (3)]

- R\&D and innovation activities (Article 7)

- Domestic Content Level (TKDN)

Chapter 8 paragraph (1)

a. Percentage of use of TKDN KBL-Based BatteryBased components two and/or three-wheeled

b. Percentage of use of TKDN KBL-based components of four-wheeled batteries or more

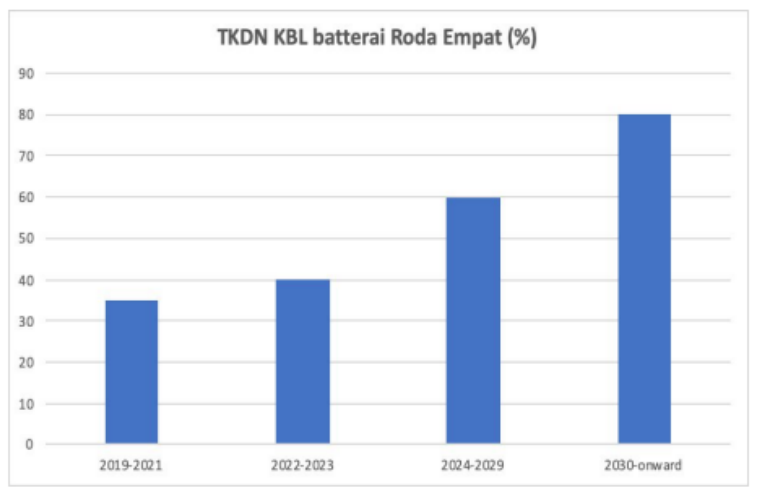

Figure 2. Percentage of TKDN KBL Battery four and/or more

Import permit for KBL industry that has built manufacturing facilities (Article 11). Contains supporting components that include:

- Incompletely KnockDown /IKD); and/or

- Complete break-down (Completely Knock Down / CKD)

\section{Incentivizing}

- Fiscal and non-fiscal incentives

- Incentives for industry, individuals, universities

E. Provision of electric charging infrastructure

- SKU and private electricity installations

- SPKLU can be done by SOEs, BUMD, private

- Sparkle development assignment to PLN

- The sale of electric power to SPKLU is carried out by IUPTL holders or partners of IUPTL holders 


\section{F. Electricity prices for EVs}

- Established by the Minister of ESDM

Then there is Government Regulation (PP) Number 73 of 2019 on Taxable Goods classified as Luxury In the Form of Motor Vehicles That Are Subject to Sales Tax on Luxury Goods (PPnBM) has been added a new provision set on October 15, 2019, by President Joko Widodo. It will take effect in the next two years, namely in 2021. The new PPnBM explained that the imposition is no longer based on the vehicle's shape, but the imposition of PPnBM will be based on exhaust emissions produced by the vehicle. Thus, the greater the emissions incurred, the greater the imposition of taxes. This significantly provides an advantage for electric vehicles that are green technology.

Not only PPnBM, but the Jakarta Provincial Government also issued BBN-kb exemption regulations in buying and selling, exchanging, grant, inheritance, electric-based motor vehicles, both fourwheeled and two-wheeled, given a duty tax exemption behind the name. The regulation is contained in Governor Regulation No. 3 of 2020 on Tax Incentives on The Name of Motor Vehicles (BBN-KB) on Battery ElectricVechicle)

After that, there are rules regarding electric vehicles proclaimed by the Ministry of Transportation (Kemenhub). The policy is the Regulation of the Minister of Transportation (Permenhub) Number 45 of 2020 concerning Vehicles by Using Electric Car Drive. The vehicles included electric scooters, electric bikes, hoverboards, electric one-wheeled bicycles, and auto electric.

Furthermore, another policy is Permen Energi and Mineral Resources (ESDM) Number 13 of 2020 on The Provision of Electric Charging Infrastructure for Battery-Based Motor Vehicles set on August 4, 2020, by the Minister of ESDM. One of the most important things in creating an electric-based ecosystem is an infrastructure that includes a battery charging station called a Public Electric Vehicle Charging Station (SPKLU). The following rule is the Minister of Home Affairs Regulation No. 8 of 2020 on The Basic Calculation of The Imposition of Motor Vehicle Taxes and Duties On The Name of Motor Vehicles in 2020.

Finally, there are two regulations issued by the Ministry of Industry (Kemenperin), namely the first Permenperin No. 27 of 2020 on Specifications, Development Roadmap, and Provisions for Calculating the Value of Domestic Component Levels of Battery-Based Electric Motor Vehicles. Second,
Permenperin No. 28 of 2020 concerning BatteryBased Electric Motor Vehicles In a Complete Decomposed State and Incomplete Unraveling Vehicles (CNN Indonesia, 2020).

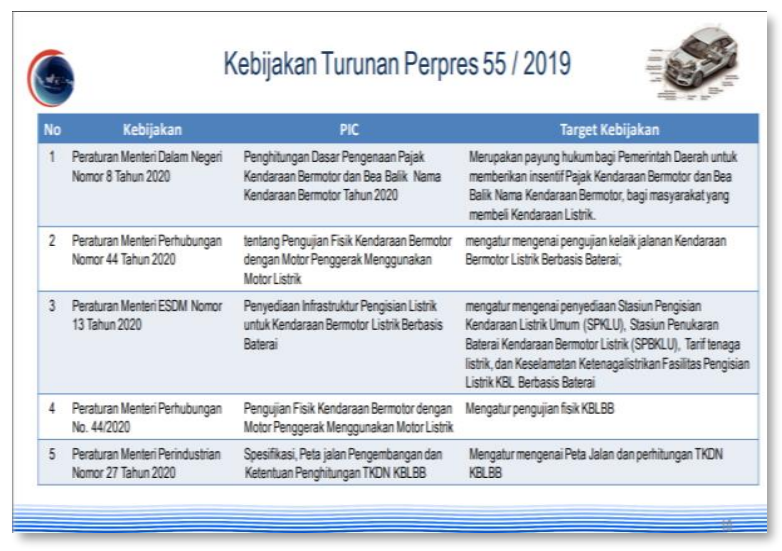

Figure 3. Derivative Policy of Presidential Regulation No. $55 / 2019$

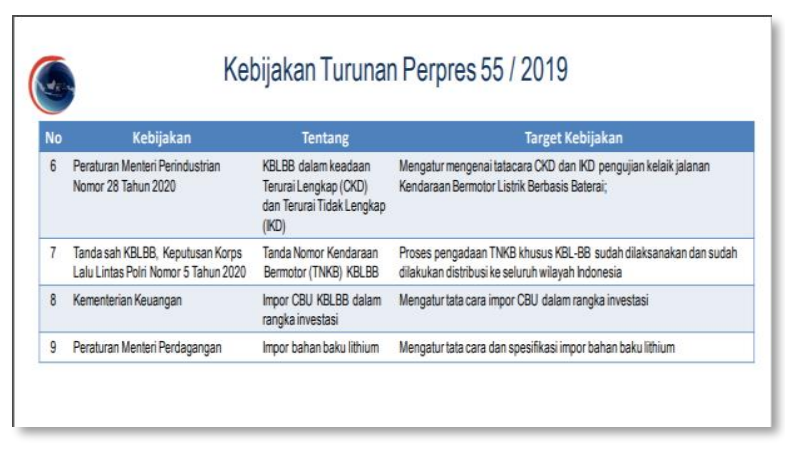

Figure 4. Derivative Policy of Presidential Regulation No. $55 / 2019$

\subsection{Impact of Electric Vehicles to Realize Environmental Resilience}

Nature and the environment are closely related to humans because humans depend on biodiversity and existing natural resources. As many as 3 billion people depend on biodiversity in the sea and land that absorbs $30 \%$ of the carbon dioxide produced by human activities (Khairina, Purnomo, \& Malawani, 2020, p. 156). Carbon dioxide is produced by motor vehicles that use fossil fuels that are not environmentally friendly.

Environmental elements are closely related to environmental resilience, which is part of national resilience. Environmental resilience is the proportional public safety of environmental hazards that come from natural or artificial processes such as human intentionality. Therefore, the study of environmental 
resilience is needed to still run their lives by minimizing environmental damage.

Environmental resilience is needed for the survival of human life in the future. It is one of the missions of the Sustainable Development Goals, precisely in goal number 13, namely in the framework of handling climate change(Khairina et al., 2020, p. 157).

The handling of climate change has initially been done to reduce the impact of global warming. In 2015, transportation accounted for $23 \%$ of total greenhouse gas emissions, so restrictions are needed on the sector. One solution to reduce greenhouse gas emissions is using electric cars because of minimal emissions and sound. Internationally the number of electric cars reached 1.2 million in 2015 and only grew in countries joined the Electric Vehicle Initiative.

The use of fossil fuels in transportation in Indonesia and causing air pollution also consumes fossil energy, whose presentation of consumption to the total final energy consumption is the largest. Due to the demand for fossil fuels, the government imports and does not rule out the possibility that imports will be done in full if fossil fuels in Indonesia have been exhausted. So, in addition to endangering air quality and the number of natural resources that cannot be renewed in Indonesia.

Based on data from the word data shows that in 2020 motor vehicles will become the most significant contributor to air pollution in Indonesia due to the use of fuel oil. As a result, several cities in Indonesia are ranked in the ten cities in Southeast Asia with the worst air quality(Setiawan, 2020).

In fact, electric cars tend to produce more negligible emissions than conventional cars that use fossil fuels because electric cars only produce $\mathrm{CO} 2$ emissions of 0-5 grams / per km. In contrast, carbon dioxide emissions from conventional cars reach 125 grams / per $\mathrm{km}$. In addition, electric cars also contribute to reducing greenhouse gas emissions, reducing air pollutants, and minimal noise pollution because it only has 21 decibels of noise.

In addition, environmentally sound development should pay attention to several indicators, including(Fitriyani, 2015, pp. 138-139):

First, the availability of ecosystems. In indicators of ecosystem availability, electric cars have positive implications for the environment because it has lower emissions and has low pollutants so that air pollution and greenhouse effects can be minimized.
Second, minimal energy use, with the use of electricity as car fuel, will undoubtedly save energy on natural resources that cannot be renewed, such as gasoline or diesel.

Third, waste control and pollution. Electric cars have 11 to $13 \%$ lower pollutants than conventional cars. Even with this fact, there has been a plan from the Ministry of the industry to use 600,000 units of electric cars by 2030 to reduce 2.7 million tons of carbon dioxide emissions.

Fourth, the increasing understanding of environmental concepts, in this case, the use of electric cars indirectly provides socialization to the community that there are alternative fuels other than fossil fuels that are much more environmentally friendly and healthier for the surrounding environment.

The presence of air pollution due to fossil fuels in motor vehicles also causes respiratory, cardiovascular, and affects oxygen in the body. Even in India, air pollution has caused 1.2 million people to die each year(Parinduri, Yusmartato, \&Parinduri, 2018, p. 118). So it can be concluded that the use of electric cars is critical in maintaining public health and building environmental resilience in Indonesia.

As national resilience is a condition of national living at any given time, it is dynamic. It contains datadata mapped in a many-to-one way to be accessible in observation and understanding of interactions.

Related to this, there is an analytic conception which is a conception of the dynamic condition of the nation in developing national strength in overcoming and facing all challenges, threats, obstacles and disturbances from outside and within the country, directly or indirectly, which endanger the integrity of the identity and survival of the nation and country (Sunardi, 1997, p. 14). Thus, there is a need for a national element to survive and grow to develop. Electric cars are a form of dynamics of fuel use aimed at minimizing damage to the environment related to quality to survive and grow so that national life is better by reducing pollution by using electric cars.

\section{CONCLUSION}

Electric vehicle policies based on the juridical basis in Indonesia are realized by regulations established by the Government of Indonesia to accelerate the automotive industry's major transition program towards the era of electric vehicles around the world. The regulation has been established by the Government of Indonesia in collaboration with all 
components of the Ministry, including the Ministry of Transportation and Energy and Mineral Resources, as well as other government agencies that also participate in accelerating the automotive industry program for electric motor vehicles. Then, the impact of using KBL itself can reduce exhaust emissions by around $10 \%$ $34 \%$ in 2030 and 2050. Not only that, KBL can reduce fuel consumption significantly and stop imports of fuel from abroad. After seeing the many positive impacts that the community will feel, the KBL Program is the answer for people whose rights have been reduced due to air pollution and unhealthy urban air. However, change will not be fast if only one wheel moves, so as much as possible, the people who understand this can distribute information and benefits for the sustainability of KBL.

\section{REFERENCES}

[1] Adiatma, J. C., \& Marciano, I. (2020). Peranan Kendaraan Listrik dalam Dekarbonisasi Sektor Transportasi Darat Indonesia. Jakarta: Institute for Essential Services Reform (IESR).

[2] CNN Indonesia. (2020, Oktober 22). 7 Regulasi yang Bikin Kendaraan Listrik 'Ngebut' di Indonesia. Retrieved September 22, 2021, from www.cnnindonesia.com:

https://www.cnnindonesia.com/teknologi/20201 022122004-384-561475/7-regulasi-yang-bikinkendaraan-listrik-ngebut-di-indonesia

[3] Kementerian Perindustrian Indonesia. (2018, November 06). Studi Mobil Listrik: Hemat Energi Hingga 80 Persen. Retrieved September 21, 2021, from kemenperin.go.id: https://kemenperin.go.id/artikel/19877/StudiMobil-Listrik:-Hemat-Energi-Hingga-80-Persen

[4] Novena, M. (2021, Februari 05). Level CO2 di Atmosfer Bakal Lewati Ambang Batas Tahun Ini. Retrieved September 21, 2021, from Kompas.com:

https://www.kompas.com/sains/read/2021/02/05 /090300023/level-co2-di-atmosfer-bakal-lewatiambang-batas-tahun-ini?page=all

[5] Tumiwa, F. (2019, September 18). Kebijakan Kendaraan Bermotor Listrik di Indonesia: Analisa Perpres No.55/1999. Retrieved September 22, 2021, from http://iesr.or.id: http://iesr.or.id/wpcontent/uploads/2019/09/Kebijakan-KendaraanBermotor-Listrik-di-Indonesia-Analisa-PerpresNo.-55-2019-Fabby-Tumiwa.pdf
[6] Pasal 1 angka 8 UULLAJ No. 22/2009

[7] Pasal 1 angka 9 UULLAJ No. 22/2009

[8] Fitriyani. (2015). Peran Pemuda Dalam Mengembangkan Eco Edu Wisata Mangrove Dan Implikasinya Terhadap Ketahanan Lingkungan Daerah (Studi Pada Perkumpulan Pemuda Peduli Lingkungan "Prenjak" Dusun Tapak, Kelurahan Tugurejo, Kecamatan Tugu, Kota Semarang, Provinsi Jawa Tengah). Jurnal Ketahanan Nasional, 21(2).

[9] Khairina, E., Purnomo, E. P., \& Malawani, A. D. (2020). Sustainable Development Goals: Kebijakan Berwawasan Lingkungan Guna Menjaga Ketahanan Lingkungan Di Kabupaten Bantul Daerah Istimewa Yogyakarta. Jurnal Ketahanan Nasional, 26(2), 155-181.

[10] Parinduri, L., Yusmartato, \& Parinduri, T. (2018). Kontribusi Konversi Mobil Konvensional Ke Mobil Listrik Dalam Penanggulangan Pemanasan Global. Journal of Electrical Technology, 3(2), 116-120.

[12] Setiawan, V. N. (2020). Kendaraan Bermotor Sumbang 60\% Polusi, Menhub Dorong Mobil Listrik. Retrieved from https://katadata.co.id/sortatobing/ekonomihijau/5fd331c7eba8f/kendaraan-bermotorsumbang-60-polusi-menhub-dorong-mobillistrik

[13] Sunardi. (1997). Teori Ketahanan Nasional. Jakarta: Hastannas.

[14] Alif, S. 2021. Kendaran Listrik di Indonesia: Prospek dan Perkembangannya. Retrieved September 30, 2021, from https://www.ui.ac.id/kendaraan-listrik-diindonesia-prospek-perkembangannya/

[15] Arsari, D. T. (2020). Legalitas Penggunaan Sepeda Listrik sebagai Alat Transpotasi Menurut Perspektif Hukum Perdagangan di Indonesia. Jurist-Diction, 3(3), 903-920.

[16] Dawami, M. D. N., Heryanto dan Akhmad, W. D. (2020). Kajian Tentang Uji Jalan Kendaraan Listrik dengan Studi Kasus Perjalanan Bandung Jakarta. Jurnal Teknologi Elektro Universitas Mercu Buana, 11(2), 64-71.

[17] Hartriani, J. (2021). Mobil Listrik Ramah Lingkungan. Jurnalisme Data. Retrieved September 30, 2021, from https://www.google.com/amp/s/katadata.co.id/a 
mp/jeany/indografik/60d0418e60ed8/mobillistrik-ramah-lingkungan

[18] Kementerian Perhubungan Republik Indonesia. (2020). Kemenhub Terbitkan Regulasi Kendaraan Bermotor Listrik. Retrieved September 30, 2021, from http://www.dephub.go.id/post/read/kemenhubterbitkan-regulasi-kendaraan-bermotor-listrik
[19] Kumara, N. S. dan Sykareyasa, I. W. (2009). Tinjauan Perkembangan Kendaraan listrik Dunia hingga Sekarang. Teknologi Elektro, 8(1), 74-82.

[20] Rahman, M. A. (2013). Pembuatan Mobil Listrik untuk Solusi Transportasi Ramah Lingkungan (Mobil Baskara). Jurnal Riset Daerah, 12(2), 1819-1837.

[21] Wirabrata, A. (2019). Percepatan Program Kendaraan Bermotor Listrik di Indonesia. Info Singkat, 11(14), 19-24. 